\title{
ІЗ ДОСВІДУ ВПРОВАДЖЕННЯ ЗМІШАНОГО НАВЧАННЯ ПРИ ВИВЧЕННІ АНГЛІЙСЬКОЇ МОВИ ЗА ПРОФЕСІЙНИМ СПРЯМУВАННЯМ
}

\author{
М. М. Прокопчук \\ доцент кафедри мовної підготовки \\ Україна, Київ, Інститут державного управління та наукових досліджень з ичиільного захисту
}

DOI: https://doi.org/10.31435/rsglobal_ws/30042020/7033

\section{ARTICLE INFO}

Received: 20 February 2020

Accepted: 16 April 2020

Published: 30 April 2020

\section{KEYWORDS}

blended learning, English for Specific Purposes, foreign language professional competence, information and communication technology.

\begin{abstract}
The article deals with the issue of blended learning adoption into teaching the second (master's degree) level in the field of expertize 281 'Public Administration' seekers English for Specific Purposes.

The foreign professional language new methodology introduction aims to solve the problem of qualitative compensation of learning content by the retrainees: the Civil Protection and Fire Safety professionals, aircommunicators and firefighting radiotelephone operators as the result of a high level of classes missing caused by occupational necessity.
\end{abstract}

Citation: M. M. Prokopchuk. (2020) Blended Learning Approach to English for Specific Purpose: Practical Experience. World Science. 4(56), Vol.3. doi: 10.31435/rsglobal_ws/30042020/7033

Copyright: (C) 2020 M. M. Prokopchuk. This is an open-access article distributed under the terms of the Creative Commons Attribution License (CC BY). The use, distribution or reproduction in other forums is permitted, provided the original author(s) or licensor are credited and that the original publication in this journal is cited, in accordance with accepted academic practice. No use, distribution or reproduction is permitted which does not comply with these terms.

Вступ. Ратифікація Угоди про асоціацію між Україною та Європейським Союзом спричинила зростання попиту на фахівців, які володіють іноземною мовою на рівні, що $\epsilon$ достатнім для здійснення ефективної комунікації у професійному оточенні, здатні швидко адаптуватись до складних, непередбачуваних ситуацій та можуть використовувати нові, нестандартні стратегічні підходи для розв'язання професійних завдань.

На кафедрі мовної підготовки Інституту державного управління та наукових досліджень 3 цивільного захисту (далі Інститут) переважну кількість слухачів складають фахівці сфери цивільного захисту, пожежної безпеки, публічного управління та адміністрування, диспетчери та радіотелефоністи пожежного зв'язку для яких володіння англійської мовою є необхідної умовою для здійснення посадових обов'язків.

Значне зростання обсягів інформації i прискорення циклу іiі відновлення при обмеженому терміні навчання, інтегрований характер підготовки фахівців різних підрозділів Державної служби України 3 надзвичайних ситуацій вимагають адаптації дидактичного i науково-методичного забезпечення навчального процесу, його предметного та процесуального аспектів до сучасних умов.

Аналіз останніх досліджень і публікацій. Питання створення ефективної методики навчання англійської мови за професійним спрямуванням (АМПС) із залученням новітніх технологій були в центрі уваги низки вітчизняних та зарубіжних науковців, серед яких особливої уваги заслуговують дослідження І. П. Биконі, Н. В. Морзе, З. К. Соломко, J. Stewart та ін.

Виділення невирішених раніше частин загальної проблеми. Однак актуальним залишається розробка покрокового запровадження змішаного навчання в умовах необхідності швидкої адаптації до умов вимушеного виконання професійних функціональних обов'язків в режимі дистанційного навчання.

Виклад основного матеріалу. Визначити переваги змішаного навчання над традиційними формами організації навчальної діяльності та описати методику запровадження змішаного 
навчання на кафедрі мовної підготовки Інституту державного управління та наукових досліджень 3 цивільного захисту в умовах вимушеного переходу до дистанційного навчання.

У 2019 - 2020 навчальному році з метою пошуків шляхів оптимізації навчання АМПС на кафедрі мовної підготовки Інституту було здійснено моніторинг відвідування за допомогою анкетування близько 100 слухачів мовних курсів.

Відповідно до отриманих даних, близько 80 \% пропусків були спричинені виробничою необхідністю, 15 \% занять було попущено через хворобу, 5 \% - через недостатній рівень мотиваційної бази.

Враховуючи неможливість значної кількості слухачів бути присутніми на заняттях із мовної підготовки, спричинену виробничою необхідністю, 78 \% слухачів висловили бажання спробувати поєднувати традиційні форми вивчення АМПС та роботу із навчальними англомовними платформами, мобільними додатками, веб-сервісами спочатку під керівництвом вчителя, що створює передумови для запровадження змішаного навчання 3 поступовим переходом до самостійного опанування АМПС.

Під змішаним навчанням (blended learning) розуміємо такий вид методики, коли відбувається поєднання он-лайн навчання, традиційного та самостійного навчання.

Повторне опитування слухачів, які розпочали вивчення АМПС із використанням навчальної платформи My English Lab (MEL), мобільного додатку QuizLet та Viber, дозволило виокремити додаткові переваги змішаного навчання у порівнянні із традиційним, а саме,

$\checkmark$ вдосконалення умінь користуватися соціальними мережами, технологіями сучасного дистанційного навчання та більш швидке орієнтування в англомовному інформаційному просторі;

$\checkmark$ врахування особистих потреби та специфіки професійної та навчальної діяльності слухачів (особисті вподобання, домінантний типу навчального інтелекту, біоритмів активності);

$\checkmark$ можливість повторення, повернення у разі необхідності до навчального матеріалу 3 метою його уточнення, закріплення, проміжного контролю;

$\checkmark$ виховання вольових якостей особистості (самодисципліни, самоорганізованості);

$\checkmark$ планування робочого дня для ефективного використання робочого та вільного часу;

$\checkmark$ контроль часового простору та змісту навчання (внутрішня мотивація) та підвищенням ефективності навчального процесу за рахунок можливостей навчальної програми (зовнішня мотивація);

$\checkmark$ перехід від ролі пасивного об'єкту навчання до активного учасника та творця власного навчального простору; засобами IT;

$\checkmark$ зростання рівня залученості слухачів до навчання як результат соціальної взаємодії

$\checkmark$ зменшення матеріальних витрат на паперові носії змісту навчання;

$\checkmark$ перехід від вчитель-орієнтованої до студент-орієнтованої моделі навчання.

Крім того, перехід до змішаного навчання дозволив:

- оновити змістовний, операційно-діяльнісний компоненти вивчення АМПС і вдосконалити його контрольно-регулятивний та стимулювально-мотиваційний компоненти [6, с. 365].

- задовольнити потреби слухачів у здійсненні комунікації в режимі викладач - студент, викладач - студенти, студент - студенти;

- надати освітні послуги тим слухачам, які відсутні через виконання службових обов'язків (чергування, участь у пошуково-рятувальних роботах, перебування за кордоном для участі в міжнародних місіях тощо);

- здійснити інтегративне формування іншомовної професійної компетентності (ІПК) разом із з предметною інформаційною компетентністю (ПІК).

Під ІПК розуміємо комплексну якість особистості, набутою в процесі вивчення англійської мови, яка складається із лінгвістичних, комунікативних і соціокультурних знань, професійних умінь і особистих ставлень, базується на досвіді та проявляється у загальній здатності й готовності до успішної діяльності у іншомовному середовищі [2, с. 7].

Слід за Н.В. Морзе та А.Б. Кочаряном розглядаємо ПІК як здатність слухача застосовувати в конкретній життєвій, навчальній та дослідницькій ситуації, в тому числі проблемній, набуті знання, уміння, навички, способи діяльності щодо добору відповідних IT та 
ïx використання для пошуку необхідних даних, їх аналізу, організації, перетворення, зберігання, передавання 3 дотриманням етичних і правових норм та вирішення завдань предметної галузі [4, с. 33].

Ми погоджуємось 3 думкою J. Stewart, що для успішного впровадження змішаного навчання, по-перше, необхідні певні умови: по-перше, викладачі та слухачі повинні бути підготовлені до використання ІКТ у навчальному процесі, по-друге, має бути спеціальний технічний центр, що зможе надавати технічну підтримку, забезпечувати відповідну швидкість Інтернету [7].

На нашу думку, не менш важливим $є$ наявність методичної та адміністративної підтримка навчального процесу, готовність як викладацького складу, так і керівництва навчального закладу гнучко та чутливо ставитись до викликів сучасності (глобального проникнення IКТ у всі сфери людської діяльності) та нагальних потреб користувачів освітніх послуг (мати можливість самостійно опановувати матеріал у разі відсутності на занятті).

Імплементація змішаного навчання в Інституті проходила із дотриманням шести процедурних пунктів:

1) лідерства, яке має на меті сприйняття змішаного навчання усіма учасниками навчального процесу, з тим, щоб воно стало частиною філософії та культури навчального закладу;

2) професійного розвитку всіх учасників навчального процесу, що забезпечує виконання завдань, визначених дорожньою картою впровадження нової методики вивчення іноземної мови;

3) реорганізація навчального прочесу при якому, викладачі та слухачі чітко розуміють напрямки реорганізації і $є$ обізнаними щодо позитивних змін та кінцевих результатів навчальної діяльності;

4) прийняття рішення придбати ичифровий контент для впровадження онлайнових та змішаних технологій навчання;

5) розширення технологічної бази, що передбачає наявність відповідної технологічної інфраструктури;

6) безпосереднього здійснення навчальної діяльності, в процесі організації якої використовуються:

- цифрові інтерактивні системи, що є засобами доставки навчального змісту, даних про успішність слухачів у режимі реального часу;

- системою управління навчанням;

- системи управління контентом;

- засоби інформування слухачів, що використовуються під час безпосереднього навчання, так і за межами навчальної аудиторії.

Інститутом було підписано договір про партнерство 3 міжнародною освітньою компанією Пірсон (Pearson) в галузі поліпшення якості іншомовної освіти в закладах вищої освіти України.

Відповідно, на території закладу були проведені презентаційна зустріч, практичний семінар та безпосереднє навчання користування навчальної платформою MEL для викладачів та слухачів мовних курсів Інституту.

Починаючи 3 жовтня 2019 - 2020 навчального року розпочато роботу двох пілотних груп за навчальними посібниками «Speak out» автора J. Wilson із доступом до інтерактивної навчальної платформи MEL.

Серед головних дидактичних функцій, що реалізуються при змішаному навчанні при активному залученні IT, виокремлюють:

- пізнавальну: використовуючи комп'ютерні технології та Інтернет слухачі отримують професійно важливі знання засобом АМПС;

-розвиваючу: робота слухачів із MEL крім активації лексичного, граматичного інструментарію, сприяє формуванню та розвитку фото-візуальних навичок, навичок нелінійного мислення, інформаційної гігієни, соціально-емоційних навичок спілкування тощо;

- тренувальну: слухачі мають можливість самостійно виконувати завдання, перевіряти свій рівень знань та умінь із певної теми у разі неможливості бути присутнім на занятті;

•діагностичну: викладач має змогу швидко здійснити контроль та з'ясувати рівень засвоєння навчальної теми слухачами; 
•комунікативну: під час роботи слухачів з MEL, ведучи діалог із комп'ютером, студенти мають можливість здійснювати комунікацію із віртуальними носіями мови, долати мовний бар'єр, страх спілкування тощо [3].

Змістовний та операційно-діяльнісний компоненти навчання AMПС із залученням MEL реалізуються за допомогою:

1) навчального мультимедійного контенту (відео, аудіо, опції запису та прослуховування власного мовлення, оптимізованої системи вправ для формування мовних навичок та комунікативних умінь);

2) перспективного планування занять (викладач може гнучко використовувати запропонований контент, обирати необхідні складові предметного та процесуального аспектів навчання АМПС);

- педагогічних інструментів контролю навчального процесу в межах частини заняття / всього заняття / навчального модуля / навчального курсу, що, в свою чергу, передбачає гнучкість у доборі викладачем не лише змісту, форм навчання, але й і контролю, оскільки викладач має змогу:

- встановлювати темпоральні обмеження (час, передбачений на виконання конкретного завдання), кількість спроб виконання як для окремого студента, так і всієї групи;

- обирати завдання для роботи в класі та /або самостійного опанування;

- здійснювати постійний моніторинг за навчальною діяльністю слухачів;

- об’єктивну картину рівня сформованості ІПК слухачів;

3) інструментів зв'язку, що озброюють всіх учасників навчального процесу додатковими можливостями для комунікації як із групою, так і індивідуально (відправлення повідомлень, нагадувань про завдання для самостійного/домашнього виконання);

4) палітри діагностичних інструментів, яка акумулює інформацію про кількість часу, витраченого слухачем на виконання окремого завдання в межах кожного модуля, здійснюють оцінювання рівня сформованості мовних та мовленнєвих навичок, кількість зроблених спроб (помилок);

5) вбудованих тестових завдань, що дозволяють здійснювати поточний та кінцевий контроль рівнів навчальних досягнень студентів, результати якого можуть враховуватись при нарахуванні балів студентам як за роботу, виконану на платформі, так і за самостійну роботу;

6) гнучкої системи вправ $i$ завдань, які допомагає оптимально розподіляти аудиторні години та години для самостійної роботи, надають студентам спеціальні навчальні засоби для формування умінь визначати власні цілі, ставити перед собою конкретні завдання, обирати шляхи і способи їх реалізації під час самостійної роботи,

7) петлі зворотного зв'язку, за рахунок роботи а) програмного забезпеченням, яке перевіряє правильність виконання кожного завдання, надаючи підказки та посилання на навчальний матеріал, який потрібно повторити для успішного виконання завдання та б) викладача, що відправляє повідомлення студентам та нагадує про завдання, що необхідно виконати, встановлюючи кінцевий термін виконання та кількість можливих спроб, та реалізувати студент-орієнтовану модель навчання;

8) можливості для вдосконалення навчальної автономії слухача: MEL презентує інформацію про цілі та результати навчання як для окремої вправи, так і навчальних модулей.

Під навчальною автономією розуміємо навчання, що здійснюється за рахунок опосередкованого керування викладачем освітнім процесом з метою самостійного оволодіння слухачами іншомовною комунікативною компетентністю [1, с. 9].

В методиці навчання АМПС виокремлюють три рівні навчальної автономії студентів:

1) часткову автономію з внутрішнім самоконтролем та із зовнішнім автоматизованим контролем (викладач визначає мету, завдання, шляхи їхньої реалізації, контролює процес і результат виконання самостійної роботи);

2) напівавтономію (викладач визначає мету і завдання, надає студентам відносну свободу щодо добору шляхів, у тому числі й із запропонованих, та ходу виконання завдання, контролює його результат);

3) умовно повну автономію (передбачається самостійне визначення студентом рубіжних і кінцевих цілей $з$ урахуванням програмних вимог та індивідуальних потреб; можливість 
консультування за потреби 3 викладачем; самостійна реалізація поставлених завдань; самоконтроль і самокорекція, оцінювання результатів) [1, с. 10].

Відповідно до Національної рамки кваліфікацій у процесі опанування АМПС важливою складовою інтегральної компетентності є відповідальність та автономія, рівень володіння якої чітко регламентується при описі кожного кваліфікаційного рівня.

Наприклад, у разі оволодіння АМПС на рівні В2 це здатність продовжувати навчання iз значним ступенем автономії, та , відповідно, для рівня $\mathrm{C} 1$ - із високий рівнем автономії.

Необхідно зауважити, що високий рівень автономії може бути досягнутим за умов:

а) вдосконалення навчально-стратегічної компетентності, яка базується на здатності особистості до автономного навчання, мовної усвідомленості та рефлексивної діяльності;

б) забезпеченні поступового підвищення рівня автономії від несамостійного до часткової автономії до умовно повної, яка співвідноситься 3 відносно гнучким видом управління навчально-пізнавальною діяльністю в процесі формування ІПК;

в) відповідальність за результати власного навчання, що передбачає бажання і здатність ініціювати власну діяльність навчання і керувати нею стосовно усіх ㄲï аспектів;

г) забезпечення творчого, проблемного характеру завдань до запропонованої системи вправ;

д) створення ситуацій, що викликають у слухачів бажання продемонструвати свої здібності;

е) забезпеченні відчуття успіху;

ж) інформування слухачів про результати їхніх досягнень у ході виконання запропонованої системи вправ для формування та вдосконалення ІПК [5, с. 222]

Висновки та пропозиції. В умовах інтегрованого характеру іншомовної підготовки фахівців різних підрозділів ДСНС, необхідності постійного оновлення дидактичного і науковометодичного забезпечення навчального процесу змішане навчання сприяє:

1) ефективному формуванню та вдосконаленню мовних і мовленнєвих навичок;

2) вдосконаленню навчальної автономії слухачів,

3) моніторингу за навчальною діяльністю слухачів, надаючи викладачеві можливість отримати об'єктивну картину набуття професійних навичок володіння іноземною мовою;

4) реалізації студент-орієнтованої моделі навчання;

5) залученню більш широкого контингенту співробітників ДСНС до вивчення АМПС;

6) переходу від репродуктивної діяльності до творчої і консультативної;

7) формуванню індивідуальних освітніх траєкторій для слухачів із різним пізнавальним потенціалом і типами мисленевих процесів;

8) створенню умов для ефективної самостійної роботи і самонавчання протягом життя співробітників ДСНС;

9) підвищенню рівня професійної мовної підготовки Державного Підприємства Мобільний Рятувальний Центр в системі ІНСАРАГ.

\section{ЛІТЕРАТУРА}

1. Биконя О. П. Теоретико-методичні засади самостійної позааудиторної роботи з англійської мови студентів економічних спеціальностей / автореф. дис. на здобуття наук. ступеня док. пед. наук : 13.00.02. Київ, 2017.

2. Дивнич $Г$. А. Англомовна компетентність як чинник функціонування механізмів державного управління в умовах євроінтеграції України / автореф. дис. на здобуття наук. ступеня канд. держ. упр. наук : 25.00.02. Чернігів, 2018.

3. Зубов А. В., Зубова И. И. Информационные технологии в лингвистике. М.: Академия, 2004.

4. Морзе Н. В., Кочарян А. Б. Модель стандарту ІКТ-компетентності викладачів університету в контексті підвищення якості освіти // Інформаційні технології і засоби навчання . №5. 2014. С. 27-39.

5. Соломко 3. K. Автономія як основа самостійної роботи 3 іноземної мови студентів немовних спеціальностей // Вісник Київського національного лінгвістичного університету. Сер.: Педагогіка та психологія. Вип. 21. 2012. С. 220-229.

6. Федоренко О. М. До питання про модель професійно-спрямованої іншомовної підготовки студентів юридичних спеціальностей // Вісник Чернігівського національного педагогічного університету. Сер.: Педагогічні науки. Вип. 111. 2013. С. 363-367

7. Stewart, J. M. A blended e-learning approach to intercultural training // Industrial and Commercial Training. № 34(7). 2002. C. 269-271. 